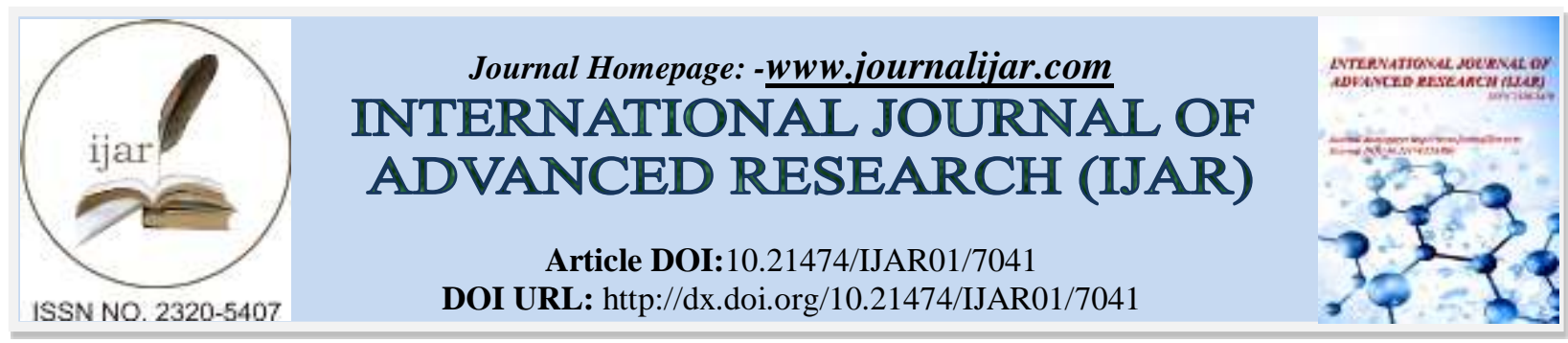

RESEARCH ARTICLE

\title{
COMBINED APPLICATION OF EDIBLE COATINGS AND PASSIVE REFRIGERATION TO EXTEND THE SHELF-LIFE OF FRESH TRUFFLES.
}

\section{Zurlini, E. Umiltà, A. Montanari and A. Brutti.}

Stazione Sperimentale per l'Industria delle Conserve Alimentari-SSICA, V.le F.Tanara 31/A, 43100 Parma, Italy.

\section{Manuscript Info}

Manuscript History

Received: 06 March 2018

Final Accepted: 08 April 2018

Published: May 2018

Keywords:-

Coating, Passive refrigeration, Protein, Truffle.

\begin{abstract}
Truffle is one of the most prestigious Italian products, with high commercial value. The growing interest generated also abroad represent incentives to the development of new preservation technologies for the extension of truffles shelf-life and, as consequence, the reduction of waste. The aim of this work is the study of the effectiveness of different types of edible coatings based on lentil proteins or their combination with chitosan, for the extension of the shelf-life of truffles of the species Tuber aestivum, stored under passive refrigeration conditions. Weight loss reduction and visual aspect of truffles have been evaluated.

Copy Right, IJAR, 2018,. All rights reserved.
\end{abstract}

\section{Introduction:-}

Truffle is a typical Italian product, characterized by unique taste and aroma, which national and international market is in great development nowadays (MELLO et al., 2006, DÍAZ et. al., 2009). The high commercial value (approximately 200 to $2000 € / \mathrm{kg}$ ) of this niche product is due not only to its typical organoleptic properties, but also to the difficulty to find it, the harvesting modes, as well as its high perishability and the consequent short shelf-life of 4-5 days on average. In fact, truffle is a seasonal hypogeous fungus, which harvesting has to be carried out only in established periods and at complete maturation. Besides, after harvesting, it rapidly loses its organoleptic properties, because of superficial microbial growth, of dehydration and of senescence. Another aspect that should be taken into account is the weight loss, that has a big economical impact. For all these reasons, some species of truffles, such as Tuber magnatum, Tuber melanosporum and Tuber aestivum, are the most expensive edible fungi available on the market. Certainly, the prestige of the sector, the positive trend of the market and the growing interest generated also abroad by these products represent incentives for the development of new preservation methodologies that could allow the extension of truffles shelf-life. For this purpose, in the last years innovative techniques such as irradiation, modified atmosphere packaging, ultrasounds, edible coatings and active packaging, together with their combinations, were largely studied (REALE et al., 2009, RIVERA et al., 2010, CIOLACU et al., 2013, CATALANO et al., 2015).

Among these methods, there is a growing interest towards the utilization of edible coatings from natural sources like polysaccharides, lipids and proteins, that could potentially replace some conventional synthetic packaging materials from petroleum, offering different advantages as the low cost, the simplicity, the versatility, the possibility to be applied on food by various methods and the renewable and biodegradable nature. Besides, they can provide barrier properties against humidity, oxygen, aroma and oils, preserving at the same time the food appearance, and they also may serve as carriers for a wide range of food additives, as anti-oxidants, antimicrobials and flavors, thus becoming 
active packaging systems (BALDWIN et al., 1995, GUILBERT et al., 1996, PORTA et al., 2013, MELLINAS et al., 2016).

In such context, proteins-based films are characterized by barrier properties to oxygen and carbon dioxide and good mechanical properties, whereas the water permeability can be overcome by the addition of hydrophobic materials, such as oils, to modify the cristallinity, hydrophobicity, surface charge and molecular size. They are water-soluble and can act as emulsifier and increase the nutritional value and aroma of food to which they are applied (LACROIX and VU, 2014).

Protein films can be obtained from structural or reserve proteins derived from animals, for example, casein, whey protein, gelatin, egg albumin, or plant sources, for example, corn, wheat, cottonseed, peanut, rice and legumes. The last ones represent an important source of different kinds of proteins with film-forming capacity (BRANDENBURG et al., 1993, SEOK and HAN, 2001, BAMDAD et al., 2006, MONTANARI and ZURLINI, 2013, SHEVKANI and SINGH, 2013), that could be isolated not only from raw materials but also from industrial by-products, produced in large amounts in Europe, that in this way could be valorized.

In recent years some works on the application of proteins-edible coatings to fresh products, among which also mushrooms and truffles, were performed (PACIONI et al., 2014), but only few films derived from legumes (SHON and CHOI, 2011).

With the purpose to improve food preservation preventing also microbial growth, antimicrobial agents could be incorporated in protein matrix or, as alternative, a combination of proteins-based films with antimicrobial materials could be applied. Among the substances used for the realization of biopolymeric and edible films with bacteriostatic function, one of the most widespread is chitosan, a deacetylated derivative of chitin, that has been found to be nontoxic, biodegradable, biofunctional, biocompatible and to have strong antimicrobial and antifungal activities. Besides it has good film-forming properties its-self (SUDARSHAN et al., 1992, AIDER, 2010). Thanking to its properties, chitosan was largely investigated as edible and active coating on fresh fruit and vegetables and also on fresh mushrooms (DEVLIEGHERE et al., 2004, KIM et al., 2006, EISSA, 2008).

Another factor that has to be taken into account for the extension of fresh products shelf-life is represented by storage conditions. Dealing with this point, passive refrigeration has been recently introduces as a cooling system for the preservation and transportation of fresh and perishable products like fruit, vegetables, meat, dairy products, fish and flowers, in ideal and controlled cold and humidity conditions without forced ventilation. One of the main advantages offered by this storage system is the uniformity of humidity above $90 \%$ and temperature at $0{ }^{\circ} \mathrm{C}$, guaranteed in different points of the chamber of PRS cell. This is allowed by passive elements that use the energy supplied by the melting enthalpy of the thermal mass, frozen beforehand by circulating refrigeration fluid at low temperature within a heat accumulator, that is able to absorb the heat that passes through the walls and the heat dissipated by the products (GHIRALDI, 2014, MOLINO, 2009).

In such context, the aim of this work is the evaluation of the effectiveness of different types of edible coatings based on lentil proteins or their combination with chitosan, for the extension of the shelf-life of truffles of the species Tuber aestivum, in terms of weight loss reduction and visual inspection. As it would be advantageous to facilitate the exportation of truffles from Italy to countries as USA, it was decided to study the combination of edible coatings and passive refrigeration. This storage system was selected on the basis of the results obtained from preliminary tests carried out with different refrigeration systems.

\section{Materials and methods:- \\ Samples:-}

Truffles of the species Tuber aestivum were provided on Italian market. The surface of each truffle was brushed just before the storage and, in the case of treated truffles, the application of edible coatings used to limit the transpiration process. The mean starting weight of samples was around $30-40 \mathrm{~g}$.

\section{Materials:-}

Lentil proteins were extracted from lentil seeds according to a procedure patented by SSICA [15]. Biological not bitter cold pressed linoleum oil and refined walnut oil were provided by Oleificio Sabo (Manno, Swiss). Highly 
viscous chitosan from crab shells (2-Amino-2-deoxy-( $1 \rightarrow 4)-\beta$-D-glucopyranan, Poly-(1,4-D-glucopyranosamine)) was purchased by Sigma Aldrich (Milano, Italy). Lactic acid was purchased by Carlo Erba Reagents (Milano, Italy).

\section{Edible coatings preparation and application to truffles:-}

Five different edible coatings were tested. More in details, two lentil proteins coating were prepared with two different vegetable oils, walnut (Juglans regia) and linoleum (Linum usitatissimum). The addition of the oil had the aim to reduce the permeability to water (VALENZUELA et al., 2013, VARGAS et al., 2011) and to limit the transpiration of truffles, thus limiting the senescence process. Each protein coating was tested alone and in combination with chitosan coating, in order to evaluate a possible further improvement of truffles preservation. The formulations of edible coatings and the corresponding codes are shown in Table 1.

Table 1:-Formulations and codes of edible coatings applied to truffles

\begin{tabular}{|c|c|}
\hline Code & Edible coating \\
\hline $\mathrm{N}$ & $6 \%$ lentil proteins with $2.5 \%$ walnut oil film (3 immersions) \\
\hline $\mathrm{NC}$ & $\begin{array}{l}6 \% \text { lentil proteins with } 2.5 \% \text { walnut oil film ( } 1 \text { immersion })+1 \% \text { chitosan in } 0.5 \% \text { lactic acid film (1 } \\
\text { immersion) }\end{array}$ \\
\hline $\mathrm{L}$ & $6 \%$ lentil proteins with $2.5 \%$ linoleum oil film (3 immersions) \\
\hline $\mathrm{LC}$ & $\begin{array}{l}6 \% \text { lentil proteins with } 2.5 \% \text { linoleum oil film }(1 \text { immersion })+1 \% \text { chitosan in } 0.5 \% \text { lactic acid film (1 } \\
\text { immersion) }\end{array}$ \\
\hline
\end{tabular}

On the basis of the procedure patented by SSICA (MONTANARI and ZURLINI, 2014), 6\% w/v lentil protein and $3 \% \mathrm{w} / \mathrm{v}$ glycerol solutions in water were prepared. $\mathrm{pH}$ was adjusted to 7.2 with $1 \mathrm{~N} \mathrm{NaOH}$. After the addition of $2.5 \%$ oil (walnut or linoleum), each solution was maintained under moderate stirring for 60 minutes. Then it was filtered on a certified test sieve with a granulometry of 355 micron and it was heated at $70^{\circ} \mathrm{C}$ for 20 minutes in order to denaturate proteins.

$1 \% \mathrm{w} / \mathrm{v}$ chitosan solution in $0.5 \% \mathrm{v} / \mathrm{v}$ lactic acid was prepared. After at least 3 hours under continuous mixing at $60^{\circ} \mathrm{C}, 1 \% \mathrm{w} / \mathrm{v}$ glycerol was added (PARK et al., 2002, LECETA et al., 2015).

All solutions were cooled to room temperature before the application.

Edible coatings were applied to truffles by dipping, immersing each sample completely in the film-forming solution for few seconds. Then, the excess of the coating was removed, putting the truffles on a large sieve. The applied coating was so dried by cold air, for at least 10 minutes.

If only one film was used, three coatings applications were performed. If a combination of protein and chitosan films was used, one application for each coating was done, followed by the application of the other one.

More in details, for a first lot of truffles all types of coatings indicated in Table 1 were tested and compared; then with a second lot only one selected coating was tested.

Taking into account the high cost and the difficulty to provide truffles, for each test three replicates were performed.

\section{Passive refrigeration:-}

The static cell for passive refrigeration, at $0^{\circ} \mathrm{C}$ and at controlled humidity $\geq 90 \%$, was purchased by PRS Passive Refrigeration Solutions $S A$ (Lugano, Switzerland) (see Figure 1a).

Preliminary tests were performed with uncoated truffles, in order to compare different storage solutions: domestic refrigeration in common refrigerator at $4^{\circ} \mathrm{C}$, industrial refrigeration in conventional cell at $20^{\circ} \mathrm{C}, 4^{\circ} \mathrm{C}$ and $0{ }^{\circ} \mathrm{C}$, all available at SSICA facilities, and PRS cell at $0^{\circ} \mathrm{C}$ with a capacity of 400L. For the storage, samples were put in wood baskets without any cover (see Figure 1b) and their weight loss was determined after 3, 6, 13, 20 days. Also in this case, three replicates were performed for each test condition.

On the basis of the results obtained, passive refrigeration was selected for the following experiments for the study of the edible coatings effects. Once coated with edible films, samples, always inside uncovered wood baskets, were stored in PRS cell. In parallel, also reference samples, corresponding to uncoated truffles, were stored in the same 
conditions. In each basket three truffles were put. Temperature and humidity were monitored during the whole storage period.

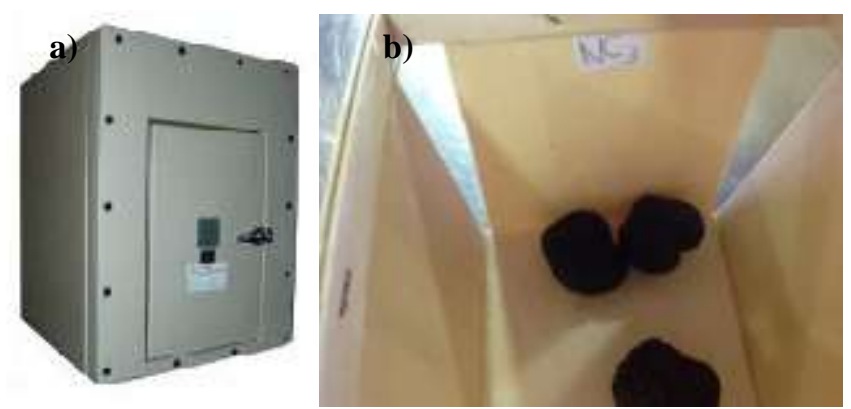

Figure 1:-a) PRS cell and b) wood baskets for the storage of truffles

\section{Shelf-life tests:-}

The shelf-life of coated and uncoated truffles stored in PRS cell at $0^{\circ} \mathrm{C}$ was followed, through the determination of weight loss and visual inspection of samples. More in details, for the first lot of truffles, the weight of samples at time 0 and after 2, 6, 13, 16 and 20 days was determined. For the second lot, the weight loss was determined after 2 , $6,9,13$ and 20 days.

For truffles of second lot coated with the LC film, also microbiological analysis were performed determining the concentration of enterobacteria, yeasts and moulds, Listeria monocytogenes and Salmonella sp. All microbiological analysis were carried out according to ISO norms (ISO 21528-2:2004, ISO 7954:1987, ISO 11290-1:1996/A1:2004, ISO 11290-2:2004, ISO 6579:2002/A1:2007).

Data analysis:-

The comparison of the significance of the data was performed using t-test.

\section{Results and discussion:-}

Preliminary tests with different refrigeration systems:-

In Table 2 it is possible to observe the values of weight loss recorded for uncoated truffles in preliminary tests with different refrigeration systems, after 3, 6, 13 and 20 days of storage.

Table 2:-Weight loss recorded in preliminary tests with in different refrigeration systems for truffles

\begin{tabular}{|c|c|c|c|c|}
\hline \multirow{2}{*}{ Refrigeration system } & \multicolumn{4}{|c|}{ Weight loss $(\mathrm{g} / 100 \mathrm{~g})^{*}$} \\
\hline & $\mathrm{t}=3$ days & $t=6$ days & $\mathrm{t}=13$ days & $t=20$ days \\
\hline $\begin{array}{l}\text { Conventional industrial cell } \\
20^{\circ} \mathrm{C}\end{array}$ & $44.20 \pm 2.55 a$ & $61.28 \pm 4.13 a$ & $74.75 \pm 2.10 \mathrm{a}$ & $75.96 \pm 1.74 a$ \\
\hline Domestic refrigerator $4^{\circ} \mathrm{C}$ & $13.71 \pm 1.61 b c$ & $24.34 \pm 3.11 b c$ & $40.84 \pm 5.18 b c$ & $50.00 \pm 6.53 \mathrm{bc}$ \\
\hline $\begin{array}{l}\text { Conventional industrial cell } \\
\qquad 4^{\circ} \mathrm{C}\end{array}$ & $19.24 \pm 1.54 b$ & $34.23 \pm 2.73 b$ & $55.27 \pm 4.44 b$ & $65.05 \pm 4.71 \mathrm{ab}$ \\
\hline $\begin{array}{l}\text { Conventional industrial cell } \\
0^{\circ} \mathrm{C}\end{array}$ & $12.15 \pm 1.25 \mathrm{c}$ & $21.14 \pm 2.17 \mathrm{c}$ & $37.97 \pm 3.51 \mathrm{c}$ & $48.97 \pm 3.74 \mathrm{c}$ \\
\hline PRS cell $0^{\circ} \mathrm{C}$ & $3.80 \pm 0.47 \mathrm{~d}$ & $4.65 \pm 1.08 \mathrm{~d}$ & $8.11 \pm 2.82 \mathrm{~d}$ & $12.48 \pm 2.82 \mathrm{~d}$ \\
\hline
\end{tabular}

*Results are expressed as mean \pm standard deviation. Values with the same letters within each column are not significantly different $(\mathrm{p}>0.05)$

As expected in conventional cell at $20^{\circ} \mathrm{C}$, the weight loss was very high from the beginning of the test, arriving at around $44 \mathrm{~g} / 100 \mathrm{~g}$ after only 3 days of storage. After 20 days, the weight loss was around $76 \mathrm{~g} / 100 \mathrm{~g}$ and samples were completely dehydrated and difficult to be cut. With other conventional systems the weight loss values were lower; however, after 20 days of storage weight losses of around 50-60g/100g were recorded and truffles were characterized by a "spongy" consistency. Best results were achieved with passive refrigeration in PRS cell at $0^{\circ} \mathrm{C}$, that allowed to record the lowest weight loss values for the whole interval of time investigated and to better preserve the internal aspect of truffles (see Fig. 2a-e). 

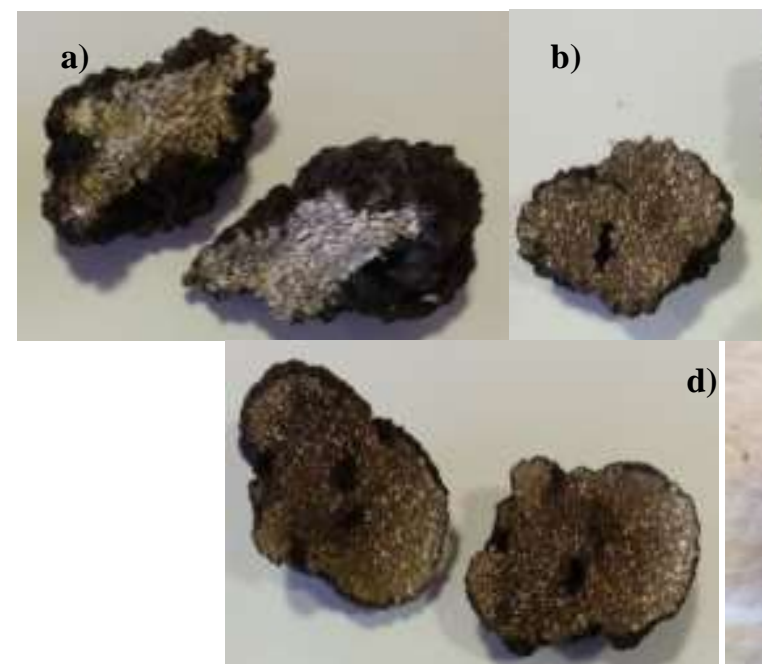

d)

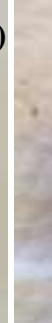

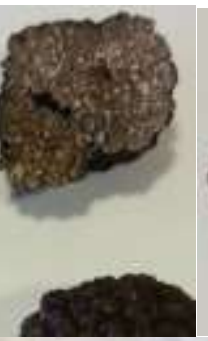
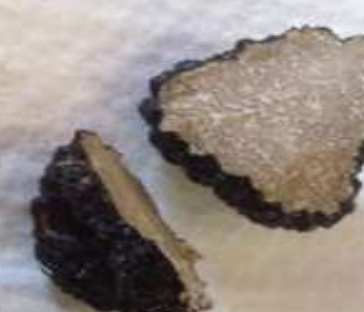

c)
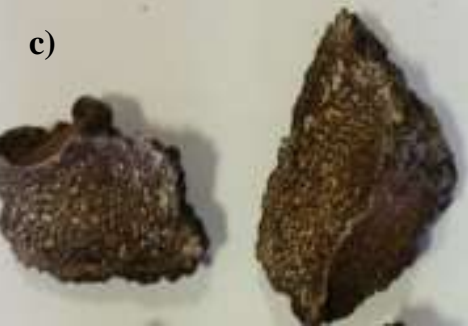

e)

Figure 2:-Cut truffles after 20 days of storage in a) conventional industrial cell at $20^{\circ} \mathrm{C}$, b) domestic refrigerator at $4^{\circ} \mathrm{C}$, c) conventional industrial cell at $4^{\circ} \mathrm{C}$, d) conventional industrial cell at $0^{\circ} \mathrm{C}$, e) PRS cell $0^{\circ} \mathrm{C}$.

The different behavior of truffles in PRS cell could be related to the absence of forced ventilation, instead present in other refrigeration systems used, that ensures higher humidity levels, as shown in Table 3. As consequence, it is possible to maintain the product more hydrated for a longer period.

Table 3:-Temperature and humidity conditions recorded in the refrigeration systems tested*

\begin{tabular}{|c|c|c|c|}
\hline Refrigeration system & Temperature $\left({ }^{\circ} \mathbf{C}\right)$ & Humidity (\%) & Description \\
\hline Conventional industrial cell $20^{\circ} \mathrm{C}$ & $23.7 \pm 0.1$ & $45.1 \pm 2.4$ & Forced ventilation \\
\hline Domestic refrigerator $4^{\circ} \mathrm{C}$ & $4.0 \pm 0.5$ & $45.5 \pm 6.9$ & Forced ventilation \\
\hline Conventional industrial cell $4^{\circ} \mathrm{C}$ & $4.0 \pm 0.1$ & $59.6 \pm 0.8$ & Forced ventilation \\
\hline Conventional industrial cell $0^{\circ} \mathrm{C}$ & $0.5 \pm 0.2$ & $83.5 \pm 2.8$ & Forced ventilation \\
\hline PRS cell $0^{\circ} \mathrm{C}$ & $0.0 \pm 0.5$ & $95.0 \pm 0.5$ & No ventilation \\
\hline
\end{tabular}

* Results are expressed as mean \pm standard deviation.

\section{Control of temperature and humidity in PRS cell:-}

In Figure 3a-b the graphs of the monitoring of humidity and temperature inside PRS cell are reported as example. Data are referred to a narrow interval of time extrapolated from the storage period. The increase peaks of temperature, to which a decrease of humidity corresponds, were determined at the moment of cell opening for the sampling of truffles. 

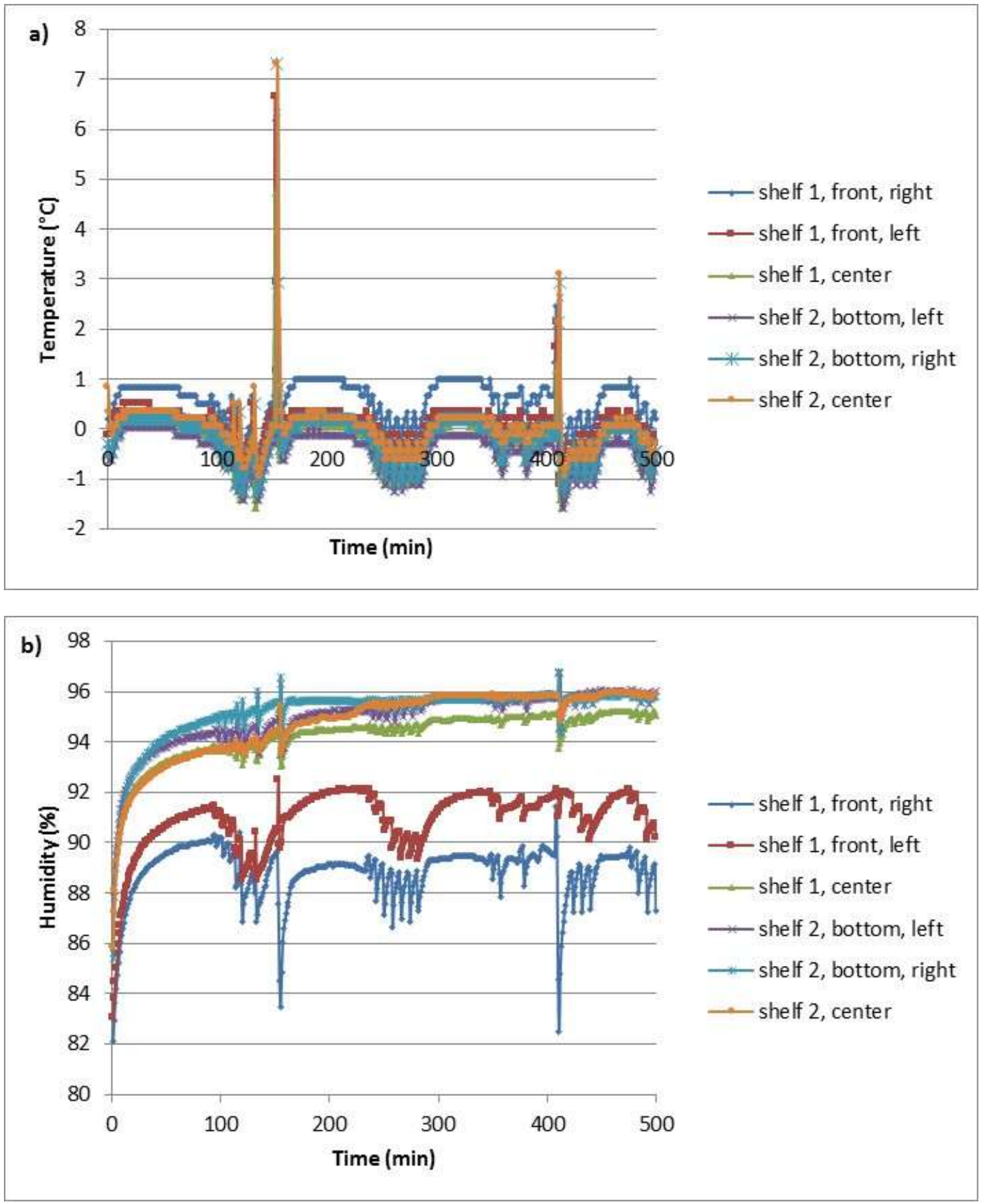

Figure 3:-Control of a) temperature and b) humidity inside Thermobox

Shelf-life tests:-

In Table 4 the values of weight loss recorded for coated and uncoated truffles of first lot, after 2, 6, 13, 16 and 20 days, are reported.

Table 4:-Weight loss recorded for coated and uncoated truffles of first lot stored in PRS cell at $0^{\circ} \mathrm{C}$ at different times of storage

\begin{tabular}{|l|c|c|c|c|c|}
\hline \multirow{2}{*}{ Sample } & \multicolumn{5}{|c|}{ Weight loss $(\mathrm{g} / 100 \mathrm{~g})^{*}$} \\
\cline { 2 - 5 } & $\mathbf{t}=\mathbf{2}$ days & $\mathbf{t}=\mathbf{6}$ days & $\mathbf{t}=13$ days & $\mathbf{t}=16$ days & $\mathbf{t = 2 0}$ days \\
\hline
\end{tabular}




\begin{tabular}{|c|c|c|c|c|c|}
\hline Uncoated & $3.04 \pm 0.50 \mathrm{a}$ & $6.61 \pm 0.71 \mathrm{a}$ & $10.47 \pm 0.83 \mathrm{a}$ & $10.62 \pm 1.24 \mathrm{a}$ & $11.14 \pm 1.30 \mathrm{a}$ \\
\hline$+\mathbf{N}$ & $4.12 \pm 1.24 \mathrm{a}$ & $5.65 \pm 1.55 \mathrm{ab}$ & $6.27 \pm 1.43 \mathrm{abc}$ & $6.71 \pm 2.08 \mathrm{a}$ & $* *$ \\
\hline$+\mathbf{N C}$ & $3.18 \pm 0.69 \mathrm{a}$ & $5.02 \pm 1.06 \mathrm{~b}$ & $6.61 \pm 1.36 \mathrm{~b}$ & $7.72 \pm 1.36 \mathrm{a}$ & $8.10 \pm 1.69 \mathrm{a}$ \\
\hline$+\mathbf{L}$ & $2.82 \pm 0.40 \mathrm{a}$ & $3.98 \pm 1.57 \mathrm{c}$ & $2.05 \pm 1.98 \mathrm{c}$ & $* *$ & $* *$ \\
\hline$+\mathbf{L C}$ & $2.61 \pm 0.76 \mathrm{a}$ & $3.84 \pm 1.19 \mathrm{abc}$ & $4.11 \pm 2.34 \mathrm{abc}$ & $4.47 \pm 2.80 \mathrm{a}$ & $4.58 \pm 2.82 \mathrm{a}$ \\
\hline
\end{tabular}

$*$ Results are expressed as mean \pm standard deviation. Values with the same letters within each column are not significantly different $(\mathrm{p}>0.05)$

**missing value due to sample unacceptableness

The quite high values calculated for standard deviation are mainly due to the natural variability of the starting product, in terms of dimensions, form and, above all, surface to volume ratio.

As it is possible to observe, the results confirm the efficacy of passive refrigeration highlighted also during preliminary tests. In fact, also uncoated truffles had a restrained weight loss.

Moreover, in all cases the presence of coating showed a tendency to decrease the weight loss with respect to uncoated truffles, stored inside PRS cell in the same conditions of humidity and temperature, even if differences are not statistically significant.

In details, the coatings containing linoleum oil ( $\mathrm{L}$ and $\mathrm{LC}$ ) allowed a major reduction of weight loss, with values for LC not higher than $5 \mathrm{~g} / 100 \mathrm{~g}$ at $\mathrm{t}=20$ days, while with those containing walnut oil ( $\mathrm{N}$ and $\mathrm{NC}$ ) the weight loss reached values around $7-8 \mathrm{~g} / 100 \mathrm{~g}$ at $\mathrm{t}=20$ days.

These results already indicate a good extension of truffles shelf-life, that is usually very short in standard conditions. In Figure 4 the comparison of weight loss trends determined for coated and uncoated truffles of first lot is reported.

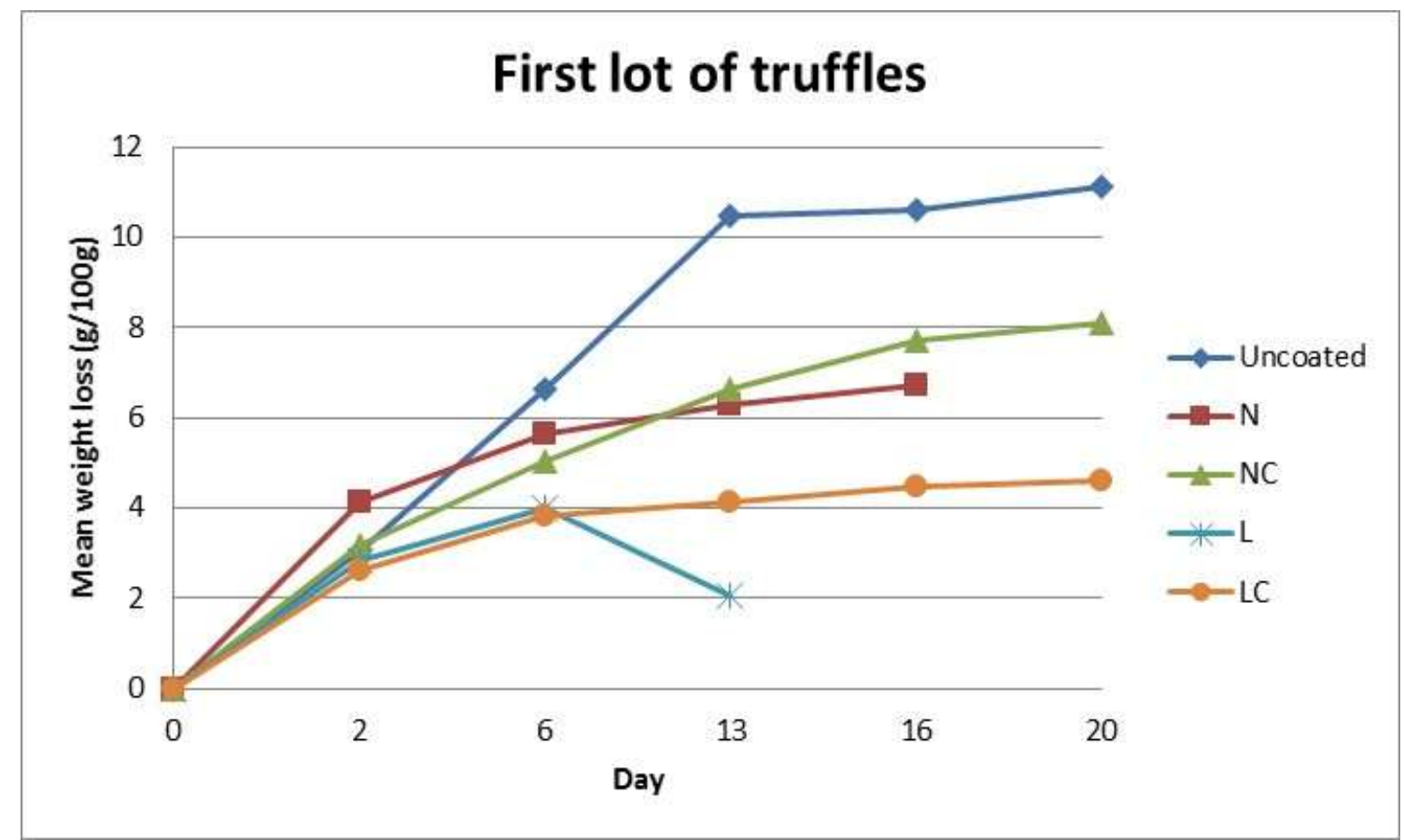

Figure 4:-Comparison between coated and uncoated truffles of first lot in terms of weight loss at different times of storage in PRS cell at $0^{\circ} \mathrm{C}$

The visual inspection of truffles of first lot revealed that all samples maintained an optimal aspect until 6 days. After 13 days, for all coated truffles the odour was still typical, but they were defined unacceptable due to loss of consistency, above all in the case of coatings containing walnut oil, and development of mould, above all in the case of coatings containing linoleum oil. 
Besides, truffles were observed at the end of the storage time (20 days) fixed for the test. Samples were cut in order to control their internal part. For all truffles, colour was uniform, but, while the typical veins were visible in the case of truffles coated with films NC and LC, they were absent in truffles coated with films N and L (see Fig. 5). Another important aspect is represented by the fact that the presence of oil in the formulation did not affect the typical odour of truffles.

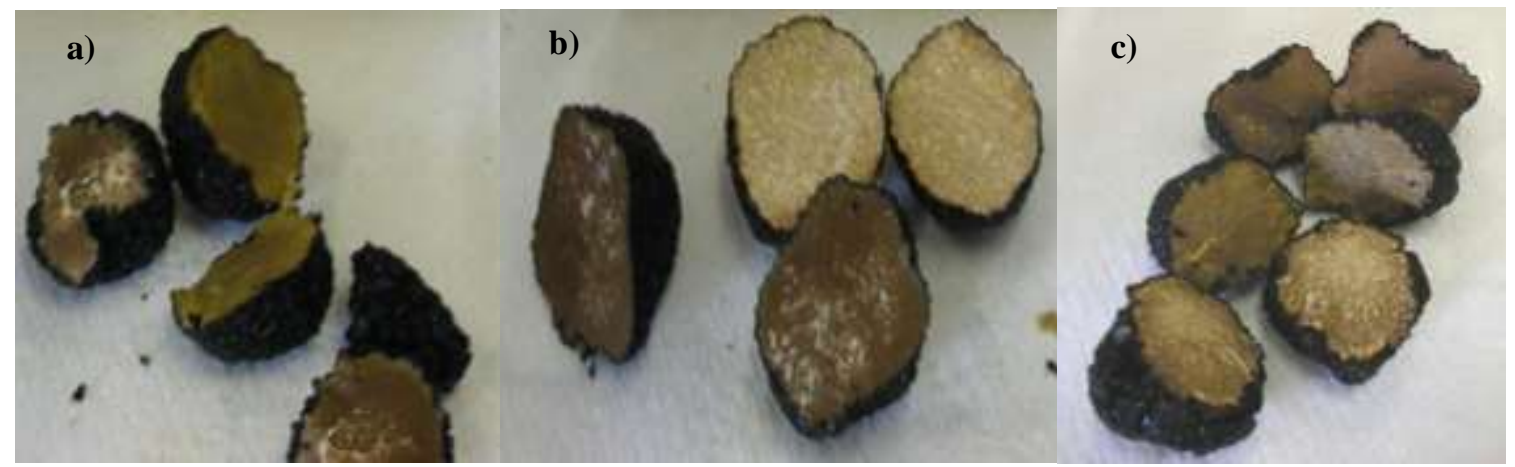

Figure 5:-Cut truffles coated with films a) L, b) LC and c) $\mathrm{NC}$ after 20 days of storage inside PRS cell at $0^{\circ} \mathrm{C}$

Taking into account the results achieved in terms of both limitation of weight loss and mould growth and of preservation of the internal aspect of the product, it was decided to perform confirmation tests with a second lot of truffles applying the coating LC. In this case, as reported in Table 5, an additional determination of weight loss at $t=9$ days was included, as for the first lot the organoleptic deterioration was recorded between 6 and 13 days for the majority of samples.

Table 5:-Weight loss recorded for coated and uncoated truffles of second lot stored in PRS cell at $0^{\circ} \mathrm{C}$ at different times of storage

\begin{tabular}{|c|c|c|c|c|c|}
\hline \multirow{2}{*}{ Sample } & \multicolumn{5}{|c|}{ Weight loss $(\mathrm{g} / 100 \mathrm{~g}) *$} \\
\cline { 2 - 6 } & $\mathbf{t}=\mathbf{2}$ days & $\mathbf{t}=\mathbf{6}$ days & $\mathbf{t}=\mathbf{9}$ days & $\mathbf{t}=\mathbf{1 3}$ days & $\mathbf{t = 2 0}$ days \\
\hline Uncoated & $3.45 \pm 0.18 \mathrm{a}$ & $5.72 \pm 1.34 \mathrm{a}$ & $7.94 \pm 0.91 \mathrm{a}$ & $9.36 \pm 1.20 \mathrm{a}$ & $11.92 \pm 4.36 \mathrm{a}$ \\
\hline + LC & $3.48 \pm 0.16 \mathrm{a}$ & $4.97 \pm 1.81 \mathrm{a}$ & $6.20 \pm 0.42 \mathrm{a}$ & $6.91 \pm 0.06 \mathrm{a}$ & $8.59 \pm 2.14 \mathrm{a}$ \\
\hline
\end{tabular}

* Results are expressed as mean \pm standard deviation. Values with the same letters within each column are not significantly different $(\mathrm{p}>0.05)$

Also in this case, in general coated truffles showed a lower weight loss than uncoated ones, even if differences are not statistically significant, for the whole time of storage provided for the test, reaching mean values around $9 \mathrm{~g} / 100 \mathrm{~g}$ for samples coated with LC film, against $12 \mathrm{~g} / 100 \mathrm{~g}$ for uncoated samples. So, the positive influence of the coating is confirmed, even if the limitation of the weight loss is lower than for the first lot, probably just because of truffles variability.

The visual inspection revealed that all samples could be considered as acceptable until 9 days. In fact, both coated and uncoated truffles were still compact, characterized by the typical odour, the surface was shiny and humid and without the presence of moulds. In correspondence to this period comparable values of weight loss were achieved for coated and uncoated truffles, around 6-8g/100g. The acceptability period was longer than that observed for the first lot, probably because of the natural variability of this kind of product. At $t=13$ days the uncoated truffles lost consistency and some samples showed the presence of small points of moulds on the surface, while coated truffles were still compact, humid and solid. The odor was still typical for both kinds of samples. At the end of storage time $(\mathrm{t}=20$ days) in both coated and uncoated truffles the development of moulds was observed, even if it was more evident in the case of uncoated ones. Besides, coated truffles were more compact. Samples were cut in order to control also their internal part and it was possible to still observe the presence of typical veins, thus demonstrating a better state of preservation (see Figure 5). On the basis of these observations, samples were overall defined acceptable, except for the presence of moulds, mainly in uncoated truffles. The presence of LC coating and in particular the linoleum oil did not influence the typical odour of truffles during the whole period of storage. 


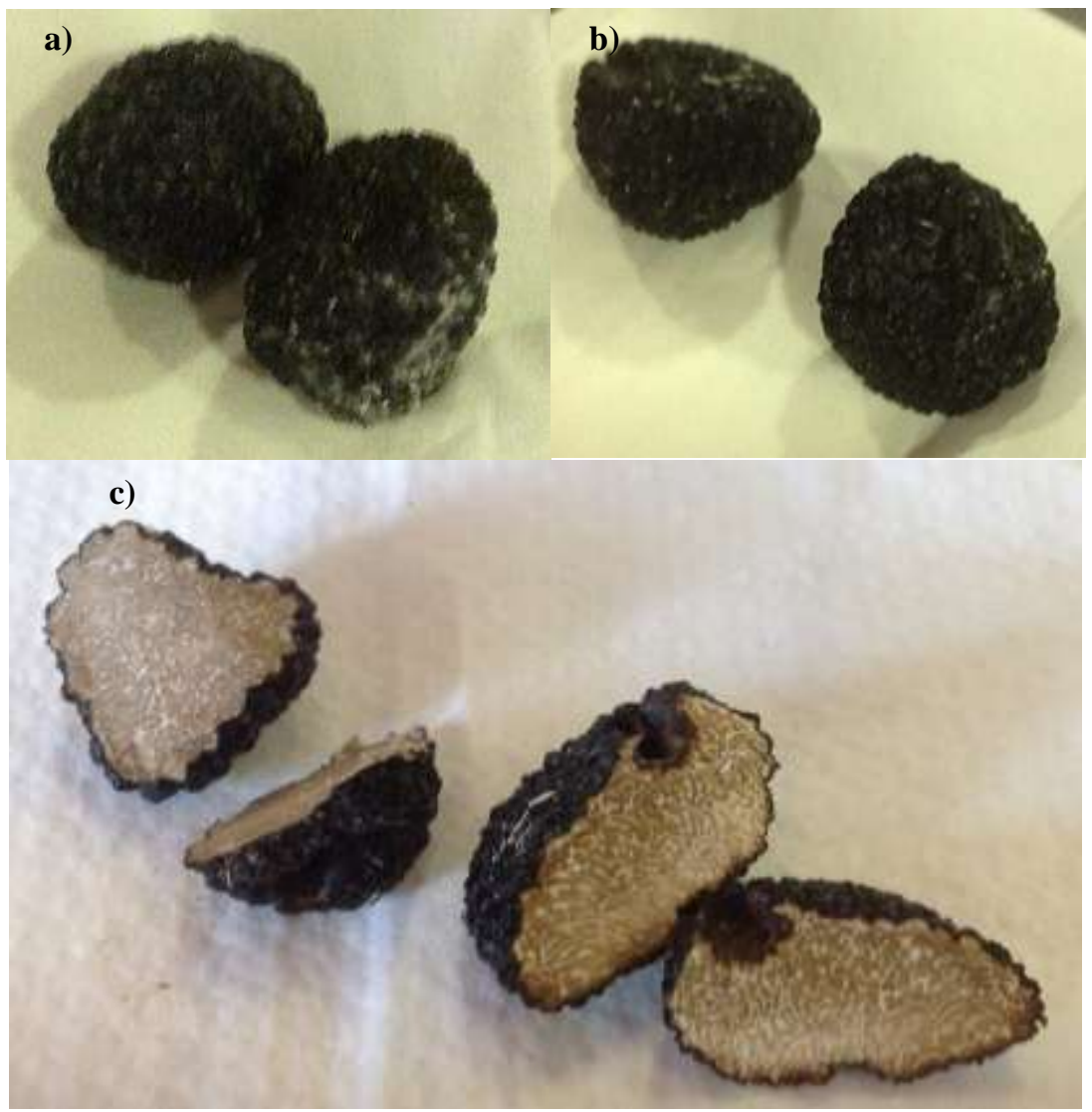

Figure 6:-Truffles of second lot after 20 days of storage inside PRS cell at $0^{\circ} \mathrm{C}$ : a) uncoated, b) coated with LC film, c) cut coated and uncoated

At the beginning of the test, the microbiological analysis on samples coated with LC film gave the following concentrations of microorganisms: $5.1 \mathrm{Log}$ ufc/g for Enterobacteria, $2.7 \mathrm{Log} \mathrm{ufc} / \mathrm{g}$ for yeasts, $2.9 \mathrm{Log}$ ufc/g for moulds and $1.5 \mathrm{Log}$ ufc/g for Listeria monocytogenes. On the contrary, Salmonella spp. was absent. This microbiological charge is in line with such kind of vegetable product. In particular, the presence of Listeria monocytogenes could be related to the origin of truffles directly from the soil, that is the ideal environment for its development (MCLAUGHLIN et al., 2011, DEFELIP, 2001). Such microbiological situation remained almost unchanged until the end of the test. In fact, no significant variations were observed at 13 and 20 days, in which the following concentrations were recorded respectively: 5.3 and $4.8 \mathrm{Log}$ ufc/g for Enterobacteria, 3.8 and $4.8 \mathrm{Log}$ ufc/g for yeasts, 2 and $2.3 \mathrm{Log}$ ufc/g for moulds and 3.4 and $1.7 \mathrm{Log} \mathrm{ufc} / \mathrm{g}$ for Listeria monocytogenes.

The two examined lots of truffles showed different behaviors, probably due to the natural variability of these fresh products and also to their preservation state at the beginning of the shelf-life test. In fact, while the samples of first lot were defined acceptable until $t=6$ days, the samples of second lot were better preserved for the whole period provided for the shelf-life test, so $t=20$ days. More in details, for the first lot, the application of edible coatings tended to more reduce the weight loss in comparison to uncoated truffles. For both coated and uncoated samples of this lot the organoleptic deterioration was observed between 6 and 13 days of storage in PRS cell at $0^{\circ} \mathrm{C}$. Instead, for the second lot, all samples showed a similar behavior until $t=9$ days. At $t=13$ days only coated samples did not show surface development of moulds. At $t=20$ days, the consistency was however acceptable, but a limited presence of moulds was observed on all samples, even if it was further reduced for truffles coated with LC film.

Comparing the results reported in Tables $\mathbf{4}$ and $\mathbf{5}$, it is possible to state that at $t=20$ days comparable weight loss values were obtained for uncoated truffles of first and second lots (around 11-12g/100g), while for LC coated truffles a lower weight loss was recorded for the first lot $(4.5 \mathrm{~g} / 100 \mathrm{~g}$ against $8-9 \mathrm{~g} / 100 \mathrm{~g})$. In both cases, a major tendency to limit the weight loss is observed from $\mathrm{t}=6$ days. 
In order to summarize, in Figure 7, the trends of weight loss for LC-coated and uncoated truffles of first and second lots are represented.

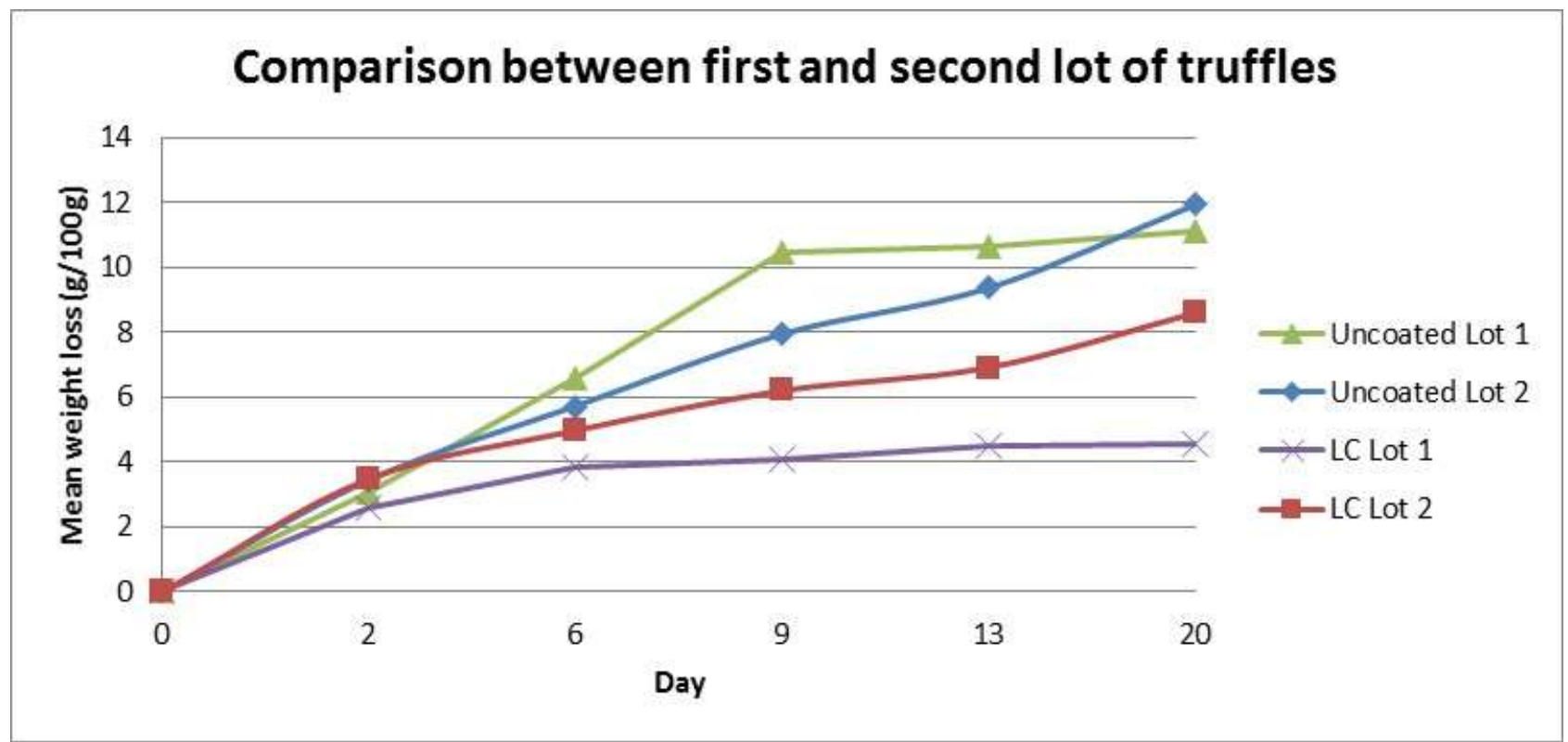

Figura 7:-Comparison between coated and uncoated truffles of first and second lots in terms of weight loss

\section{Conclusions:-}

On the basis of the results obtained from weight loss monitoring and visual inspection, it is possible to state that the combination of the passive refrigeration and the application of edible coatings on truffles opened good perspectives in terms of the extension of shelf-life until 13 days of an high value product as Tuber aestivum. In particular, three important considerations emerge. Firstly, the application of the combined coating formed by protein film with linoleum oil and chitosan film (LC) seemed to be convenient in order to reduce the transpiration, thus reducing weight loss, and to inhibit the surface development of moulds. Besides, the presence of edible coating and in particular of linoleum or walnut oil did not influence the typical sensorial characteristics of truffles, both odour and colour. Secondly, the storage in PRS cell at $0^{\circ} \mathrm{C}$ allows to extend the shelf-life also of uncoated truffles stored. Finally, the combination of edible coating and passive refrigeration permits to extend the shelf-life from few days to more than a week, with positive repercussions on marketability and economical aspects of truffles. 


\section{References:-}

1. Aider M. 2010, Chitosan application for active bio-based films production and potential in the food industry: Review, LWT- Food sci. technol., 43: 837.

2. Baldwin E.A., Nisperos-Carriedo M.O., Baker R.A. 1995, Use of edible coatings to preserve quality of lightly (and slightly) processed products, Crit Rev Food Sci Nutr, 35: 509.

3. Bamdad F., Goli A.H., Kadivar M. 2006, Preparation and characterization of proteinous film from lentil (Lens culinaris)-Edible film from lentil (Lens culinaris), Food Res Int., 39: 106.

4. Brandenburg A.H., Weller C.L., Testin R.F. 1993, Edible Films and Coatings from Soy Protein, J. Food Sci., 58: 1086.

5. Catalano P., Tremonte P., Reale A., Tipaldi L., Pannella G., Di Renzo T., Succi M., La Fianza G., Giametta F., Sorrentino E. 2015, Modified atmosphere packaging, ultrasound and chitosan: Effect of co-treatments on the shelf-life of black truffle (Tuber aestivum), Acta Hortic., 1071: 471.

6. Ciolacu L., Nicolau A.I., Hoorfar J. 2013, Edible coatings for fresh and minimally processed fruits and vegetables, Global Safety of Fresh Produce: A Handbook of Best Practise, Innovative Commercial Solutions and Case Studies, 233.

7. De Felip G. 2001, Recenti sviluppi di igiene e microbiologia degli alimenti, Tecniche nuove.

8. Devlieghere F., Vermeulen A., Debevere J. 2004, Chitosan: antimicrobial activity, interactions with food components and applicability as a coating on fruit and vegetables, Food Microbiol, 21: 703.

9. Díaz P., Ibánez E., Reglero G., Señoráns 2009, Optimization of summer truffle aroma analysis by SPME: Comparison of extraction with different polarity fibers, LWT- Food sci. technol., 42: 1253.

10. Eissa H.A.A. 2008, Effect of chitosan coating on shelf-life and quality of fresh-cut mushroom, Pol. J. Food Nutr. Sci., 58 (1): 95.

11. Ghiraldi A. 2014, Refrigerator for fresh products with temperature leveling means, United States Patent US $8,726,688$ B2.

12. Guilbert S., Gontard N., Gorris L.G.M. 1996, Prolongation of the Shelf-life of Perishable Food Products using Biodegradable Films and Coatings, LWT- Food sci. technol., 29:10, 1996.

13. ISO 21528-2:2004"Microbiology of food and animal feeding stuffs-Horizontal methods for the detection and enumeration of Enterobacteriaceae-Part 2: Colony-Count method", International Organization for Standardization (ISO)

14. ISO 7954:1987, "Microbiology-General guidance for enumeration of yeasts and moulds-Colony count technique at 25 degrees C", International Organization for Standardization (ISO)

15. ISO 11290-1:1996/A1:2004, "Microbiology of food and animal feeding stuffs - Horizontal method for the detection and enumeration of Listeria monocytogenes - Part 1: Detection method - Amendment 1: Modification of the isolation media and the haemolysis test, and inclusion of precision data", International Organization for Standardization (ISO)

16. ISO 11290-2:2004, "Microbiology of food and animal feeding stuffs - Horizontal method for the detection and enumeration of Listeria monocytogenes - Part 2: Enumeration method AMENDMENT 1: Modification of the enumeration method", International Organization for Standardization (ISO)

17. ISO 6579:2002/A1:2007, "Microbiology of food and animal feeding stuffs - Horizontal method for the detection of Salmonella spp. - Amendment 1: Annex D: Detection of Salmonella spp. in animal faeces and in environmental samples from the primary production stage", International Organization for Standardization (ISO)

18. Kim K.M., Ko J.A., Lee J.S., Park H.J., Hanna M.A. 2006, Effect of modified atmosphere packaging on the shelf-life of coated, whole and sliced mushrooms, LWT- Food sci. technol., 39: 364.

19. Lacroix M., Vu K.D. 2014, Edible Coating and Film Materials: Proteins, Innovation in Food Packaging, J.H.Han, Ed. Elsevier Ltd., 277.

20. Leceta I., Peñalba M., Arana P., Guerrero P., de la Caba K. 2015, Ageing of chitosan films: Effect of storage time on structure and optical, barrier and mechanical properties, EUR POLYM J, 66: 170.

21. Mellinas C., Valdés A., Ramos M., Burgos N., Garrigós M.C., Jiménez A. 2016, Active edible films: Current state and future trends, J. Appl. Polym. Sci , DOI: 10.1002/app.42631.

22. Mello A., Murat C., Bonfante P. 2006, Truffles: much more than a prized and local fungal delicacy, FEMS Microbiol. Lett., 260: 1.

23. McLaughlin H.P., Casey P.G., Cotten J., Gahan C.G., Hill C. 2011, Factors affecting survival of Listeria monocytogenes and Listeria innocua in soil samples, Arch. Microbiol., 193: 775.

24. Molino M. 2009, PRS Refrigerazione Passiva, Nuove tecnologie per il prolungamento della Shelf Life nelle materie prime alimentari, CIBUSTEC, Parma, October. 
25. Montanari A., Zurlini C. 2013, Biopolimero da scarti dell'industria alimentare, Italian patent 1.399.500.

26. Pacioni G., Ragnelli A.M.L., Stagnini E. 2014, Un film edibile realizzato per preservare la vitabilità e le caratteristiche organolettiche dei tartufi freschi, Italian patent AQ2011000001.

27. Park S.Y., Marsh K.S., Rhim J.W. 2002, Characteristics of Different Molecular Weight Chitosan Films Affected by the Type of Organic Solvents, JFS-E, 67: 194.

28. Porta R., Rossi-Marquez G., Mariniello L., Sorrentino A., Valeria C., Giosafatto L., Esposito M., Di Pierro P. 2013, Edible Coating as Packaging Strategy to Extend the Shelf-life of Fresh-Cut Fruits and Vegetables, J Biotechnol Biomate, 3 (4): 1000e124.

29. Reale A., Sorrentino E., Iacumin L., Tremonte P., Manzano M., Maiuro L., Comi G., Coppola R., Succi 2009, Irradiation Treatments to Improve the Shelf Life of Fresh Black Truffles (Truffles Preservation by GammaRays), JFS-M, 74 (4): 196.

30. Rivera C.S., Blanco D., Salvador M.L., Venturini M.E. 2010, Shelf-Life Extension of Fresh Tuber aestivum and Tuber melanosporum Truffles by Modified Atmosphere Packaging with Microperforated Films, JFS-E, 75 (4): 225.

31. Seok W.S., Han J.H. 2001, Physical and Mechanical Properties of Pea-Protein-based Edible Films, JFS-E, 66 (2): 319 .

32. Shevkani K., Singh N. 2015, Relationship between protein characteristics and film-forming properties of kidney bean, field pea and amaranth protein isolates, Int J Food Sci Tech, 50: 1033.

33. Shon J., Choi Y.H. 2011, Effect of edible coatings containing soy protein isolate (SPI) on the browning and moisture content of cut fruit and vegetables, J Appl Biol Chem, 54: 190.

34. Sudarshan N.R., Hoover D.G., Knorr D. 1992, Antibacterial action of chitosan, Food Biotechnol., 6:257.

35. Valenzuela C., Abugoch L., Tapia C. 2013, Quinoa protein-chitosan-sunflower oil edible film: mechanical, barrier and structural properties, LWT- Food sci. technol., 50: 531.

36. Vargas M., Albors A., Chiralt A. 2011, Application of chitosan-sunflower oil edible films to pork meat hamburgers, Procedia Food Sci, 1: 39. 